\title{
Leucine-Rich Repeat Transmembrane Protein FLRT3
}

National Cancer Institute

\section{Source}

National Cancer Institute. Leucine-Rich Repeat Transmembrane Protein FLRT3. NCI

Thesaurus. Code C29581.

Leucine-rich repeat transmembrane protein FLRT3 (649 aa, $73 \mathrm{kDa}$ ) is encoded by the human FLRT3 gene. This protein may play a role in cell adhesion. 